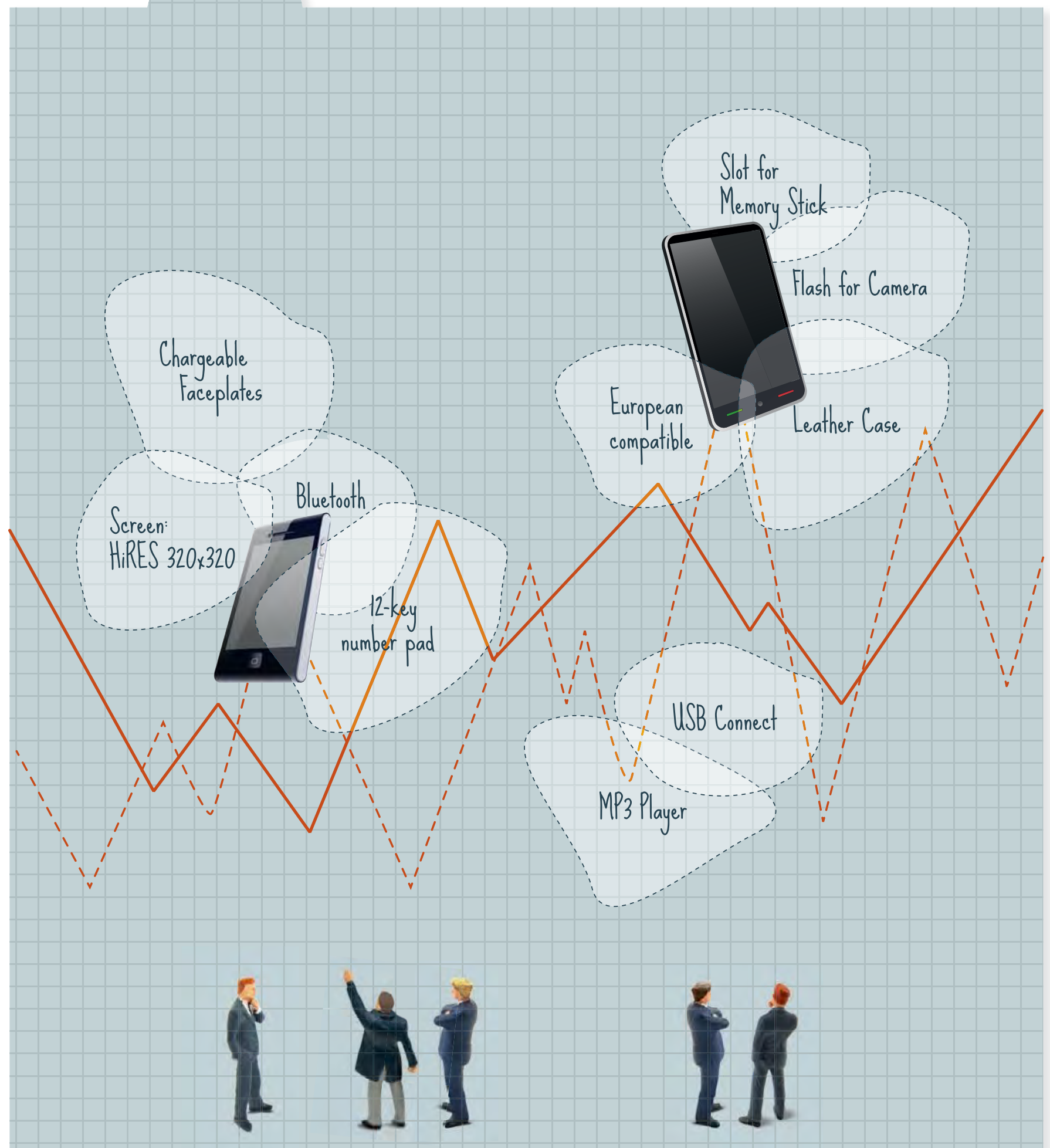

/// Trading causes participants to converge towards a consensus on feature preferences. 


\title{
PREFERENCE MARKETS IN NEW PRODUCT DEVELOPMENT
}

\author{
Ely Dahan, Arina Soukhoroukova and Martin Spann
}

Preference markets address the need for scalable, fast and engaging market research in new product development. The Web 2.0 paradigm, in which users contribute numerous ideas that may lead to new products, requires new methods of screening those ideas for their marketability and preference markets offer just such a mechanism. For faster new product development decisions, a flexible prioritization methodology for product features and concepts is tested. It scales up in the number of testable alternatives, limited only by the number of participants. New product preferences for concepts, attributes and attribute levels are measured by trading stocks whose prices are based upon share of choice of new products and features. Benefits of preference markets include speed, scalability, flexibility, and respondent enthusiasm for the method.

\section{The Challenges of "Product Development 2.0"}

In an environment of accelerating technology and short product life cycles, one in which a plethora of product concepts and features proliferates, new product development teams need fast and accurate marketing research to filter out the most promising opportunities. Smartphones, video gaming systems, home entertainment, information appliances, and other durable goods require development teams to prioritize literally hundreds of design decisions. There is a need to bridge the front-end and design phases by narrowing many features and concepts down to those key, make-or-break success factors. This requires a fast prioritization methodology, one that scales up in the number of testable product features and concepts.

The quantity of new product concepts and features to be evaluated will steadily increase, driven by the Web 2.0 paradigm, in which users volunteer new product and feature ideas over the internet. This new form of "collaborative creativity" generates thousands of possibili- ties, and demands new methods of identifying the more marketable ideas, and screening out those with lower potential. In traditional market research, the more features or product concepts to be studied, the greater the number of participants and the cost and time required. Limits on the number of questions for participants derive from bounded rationality, respondent fatigue, and time constraints. Faced with too many questions, respondents may resort to simplifying heuristics, even with tasks involving as few as $10-20$ product features.

\section{Trading Stocks to Reveal Preferences}

Scalable preference markets are a flexible new mechanism to test preferences for large numbers of new product features and concepts. Preference markets offer an ideal first-cut screening mechanism, thereby complementing other methods such as conjoint analysis and concept testing which perform better on a limited number of attributes and product concepts. By relying on the wisdom of crowds, preference markets identify
THE AUTHORS

Ely Dahan, Assistant Professor of Marketing, UCLA Medical School, Los Angeles, CA USA, elydahan@gmail.com

Arina Soukhoroukova, Research Associate, University of Passau, Germany, as@ideamarkets.com

Martin Spann, Professor of Electronic Commerce, Ludwig-Maximilians-University Munich, Germany, spann@spann.de

The article is an adapted version of Dahan, Ely, Soukhoroukova, Arina and Spann, Martin (2010),

"New Product Development 2.0: Preference Markets", Journal of Product Innovation Management, 27(7), 937-954. 
$\{$ Box 1$\}$

HOW PREFERENCE MARKETS FOR NEW PRODUCTS WORK

1. Stocks represent product features (e.g., form: brick, flip or slide phone)

2. Stock price represents market share for feature (e.g., $x \%$ market share for a sat navi sold at \$59)

3. Participants buy and sell stocks according to their expectations of a product features market share

4. Market mechanism aggregates trading behavior into market price

$\{$ Box 2$\}$

\section{BENEFITS OF THE METHODOLOGY INCLUDE}

$>$ Speed: it takes less than one hour per trading experiment

$>$ Scalability: the question capacity grows linearly in the number of traders

$>$ Flexibility: features and concepts can be tested simultaneously

$>$ Fun for participants: respondent enthusiasm for the method

$>$ High consistency and reliability across trading experiments and against independent surveys. potential good and bad ideas. By engaging in stock trading, in which the price of each stock represents the degree of preference for a product attribute level, new feature or fully integrated product concept, participants reveal their own preferences and their expectations of others' new product preferences, and converge towards an equilibrium which captures the consensus view.

Previous research on prediction markets has used stock trading to forecast actual outcomes such as election results, movie box office takings, or sporting event outcomes. Preference markets, on the other hand, do not predict actual outcomes, nor are they based upon external information. Rather, they measure expectations of others' new product preferences, based upon individual self preferences combined with insights about others. While prediction markets typically run for weeks or longer, preference markets require only minutes, as there is no outside "news" to affect the market. Participants are presented with new product concepts and then trade securities representing the competing designs. In effect, traders place bets on those concepts which they expect to curry favor with their fellow traders. Box 1 gives an overview of the steps of a preference market mechanism for the development of a new mobile phone.

\section{Applicability of Preference Markets at the Different Phases of New Product Development (NPD)}

Preference markets can be applied during the four phases of new product development. In the early idea generation and concept selection phases, preference markets can narrow potential concepts and product attributes to a manageable number, focusing resources where they will yield the greatest marginal benefit. In the later detailed design and testing \& launch phases, preference markets can help assess price sensitivity, detailed new product feature preferences, and optimal advertising and promotion. However, at these later stages (especially during testing \& launch), preference markets are only a special case of prediction markets that forecast the market potential of a product prior to introduction. A primary distinction of preference markets in the latter NPD stages is that the concepts tested need not ultimately be launched, and actual outcome is not required as is the case for prediction markets. For example, an NPD team might use preference markets to test potential advertising campaigns, price points or distribution strategies prior to product launch. Only one option will be realized based on the new product pref- 
Table 1:

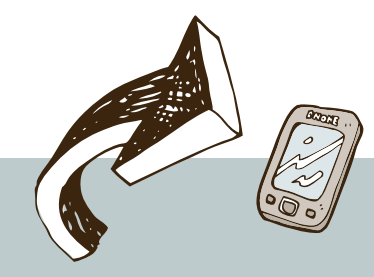

\section{PREFERENCE MARKETS AT KEY PHASES OF NEW PRODUCT DEVELOPMENT}

\begin{tabular}{|c|c|c|c|c|}
\hline & Idea Generation & Concept Selection & Detailed Design & Testing \& Launch \\
\hline $\begin{array}{l}\text { Who? } \\
\text { (Ideal respondents) }\end{array}$ & $\begin{array}{l}\text { Cross-section of people in } \\
\text { the market }\end{array}$ & $\begin{array}{l}\text { Potential consumers; } \\
\text { firm's employees }\end{array}$ & $\begin{array}{l}\text { Target market members; } \\
\text { designers \& engineers }\end{array}$ & $\begin{array}{l}\text { Target market members; } \\
\text { company managers; } \\
\text { channel }\end{array}$ \\
\hline $\begin{array}{l}\text { What? } \\
\text { (Stock types) }\end{array}$ & $\begin{array}{l}\text { Competing (i.e., mutually } \\
\text { exclusive) ideas and } \\
\text { attributes }\end{array}$ & $\begin{array}{l}\text { Competing integrated } \\
\text { product concepts }\end{array}$ & $\begin{array}{l}\text { Mutually exclusive } \\
\text { attribute levels at varying } \\
\text { prices and performance }\end{array}$ & $\begin{array}{l}\text { Final design at various } \\
\text { prices; potential ads and } \\
\text { promotions }\end{array}$ \\
\hline $\begin{array}{l}\text { How? } \\
\text { (Market formats) }\end{array}$ & $\begin{array}{l}\text { Subgroups of people trade } \\
\text { overlapping subsets of } \\
\text { rough ideas and attributes }\end{array}$ & $\begin{array}{l}\text { Subgroups of people } \\
\text { trade competing detailed } \\
\text { concepts with varying } \\
\text { prices }\end{array}$ & $\begin{array}{l}\text { Traders focus on two or } \\
\text { more attribute areas of } \\
\text { interest with some overlap }\end{array}$ & $\begin{array}{l}\text { Trade ads, channel } \\
\text { options, and the product } \\
\text { priced at different levels }\end{array}$ \\
\hline $\begin{array}{l}\text { Why? } \\
\text { (Objectives) }\end{array}$ & $\begin{array}{l}\text { Narrow many ideas and } \\
\text { attribute levels to just } \\
\text { a few }\end{array}$ & $\begin{array}{l}\text { Rate or rank the most } \\
\text { promising integrated } \\
\text { concepts }\end{array}$ & $\begin{array}{l}\text { Measure preference } \\
\text { intensity and tradeoffs } \\
\text { for features }\end{array}$ & $\begin{array}{l}\text { Design optimal pricing, } \\
\text { promotion and channel } \\
\text { strategy }\end{array}$ \\
\hline
\end{tabular}

erences of the traders, but the lack of actual outcomes does not prevent preferences from being measured. Table 1 summarizes the conclusions about who should participate in preference markets, which stock types can be tested and how these markets could be implemented. Further, it provides information on the objectives of running preference markets at the four key stages of new product development.
From Table 1, we see that preference markets appear to be particularly beneficial in the early stages of NPD as a way of prioritizing design decisions and allocating resources. They complement other market research methods, such as conjoint analysis and virtual concept testing, which perform better with a limited number of attributes and concepts, and which are geared to individual preference measurement. 
FIGURE 1:

Pictures of Features and Their Levels Used in the Studies:

6 Mutually Exclusive Smartphones (each of the 6 categories totals $100 \%$ )

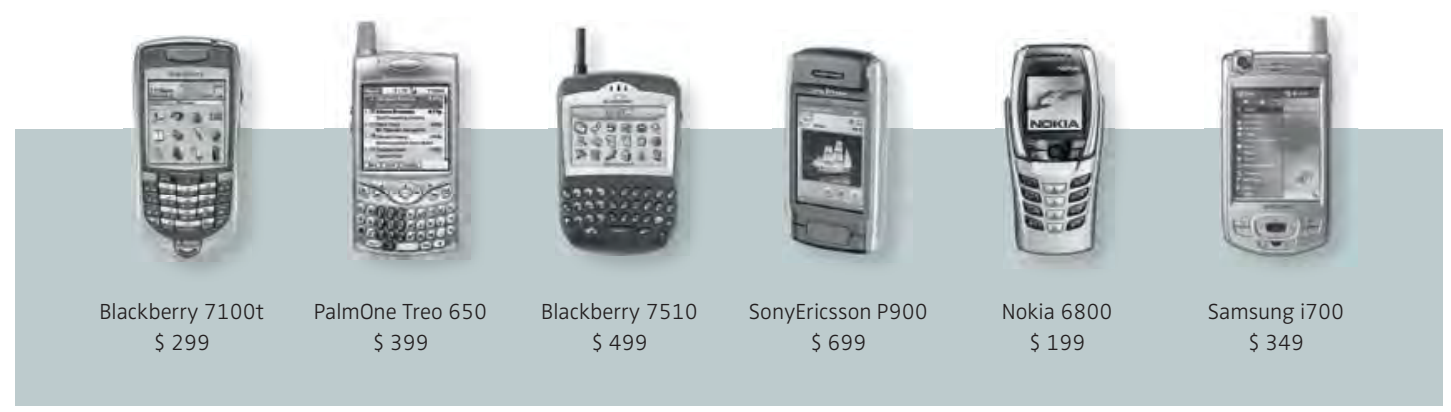

\begin{tabular}{|c|c|c|c|}
\hline Color: Basic Black & & Cell Network: Nextel & NEXIEI: \\
\hline Color: PPod Gold & & Cell Network Sprint & Sprint \\
\hline Color: iPod Silver & & Cell Network: Cingular/AT\&T & ※ cingular \\
\hline Color: iPod Metallic Blue & & Cell Network: Verizon & verizon \\
\hline Color: iPod Metallic Green & & Form: Brick & \\
\hline Color: iPod Metallic Pink & & Form: FlipPhone & \\
\hline Brand: Blackberry & : BlackBerry & Form: Slide Open & \\
\hline Brand: Motorola & (A) MOTOROLA & Oper. System: Palm & \\
\hline Brand: Nokia & NDKIA & Oper. System: Microsoft & A4. Windows \\
\hline Brand: SonyEricsson & $\bigodot_{\text {sony ficssor }}$ & & \\
\hline
\end{tabular}

19 Binary Smartphone Feature Levels (each garners between $0 \%$ and $100 \%$ "share" at the feature price shown)
30 Binary Smartphone Feature Levels (each garners between $0 \%$ and $100 \%$ "share" at the feature price shown)

\begin{tabular}{|c|c|c|}
\hline $\begin{array}{l}\text { Changeable Faceplates } \\
(\$ 10)\end{array}$ & $\begin{array}{l}\text { Video Camera Phone } \\
(\$ 79)\end{array}$ & $\begin{array}{l}\text { MiniKeyboard Input } \\
(\$ 0)\end{array}$ \\
\hline $\begin{array}{l}\text { Size: Reduce } 5^{\prime \prime} \text { to } 3^{\prime \prime} \\
(\$ 40)\end{array}$ & $\begin{array}{l}\text { MP3 Player (\$ 49) } \\
\text { FM Radio (\$ 25) }\end{array}$ & $\begin{array}{l}\text { 12-key number pad } \\
(\$ 0)\end{array}$ \\
\hline $\begin{array}{l}\text { Wt: Reduce } 60 z \text { to } 3 \mathrm{oz} \\
(\$ 36)\end{array}$ & $\begin{array}{l}\text { European compatible } \\
(\$ 30)\end{array}$ & $\begin{array}{l}\text { Stylus / Touch Input } \\
(\$ 30)\end{array}$ \\
\hline $\begin{array}{l}\text { Upgade: Mono to Color } \\
\text { (\$99) }\end{array}$ & $\begin{array}{l}\text { SLOT for Compact Flash } \\
(\$ 15)\end{array}$ & $\begin{array}{l}\text { Bletooth } \\
(\$ 49)\end{array}$ \\
\hline $\begin{array}{l}\text { Screen: HiRes } 320 \times 320 \\
(\$ 55)\end{array}$ & $\begin{array}{l}\text { SLOT for Memory Stick } \\
(\$ 15)\end{array}$ & $\begin{array}{l}\text { USB connect } \\
(\$ 15)\end{array}$ \\
\hline $\begin{array}{l}\text { Push e-Mail mode } \\
(\$ 10)\end{array}$ & $\begin{array}{l}\text { SLOT for Secure Digital } \\
(\$ 15)\end{array}$ & $\begin{array}{l}\text { WiFi wireless networking } \\
(\$ 49)\end{array}$ \\
\hline $\begin{array}{l}\text { GPS Mapping \& Navigation } \\
\text { (\$ 129) }\end{array}$ & $\begin{array}{l}\text { Memory Upgrade to } 32 \mathrm{MB} \\
(\$ 25)\end{array}$ & $\begin{array}{l}\text { Infrared } \\
(\$ 5)\end{array}$ \\
\hline $\begin{array}{l}\text { Camera: } 1 \text { Mpixel no zoom } \\
(\$ 25)\end{array}$ & $\begin{array}{l}\text { Memory Upgrade to } 64 \mathrm{MB} \\
(\$ 50)\end{array}$ & $\begin{array}{l}\text { Chip: } 166 \mathrm{mhz} 3 \times \text { speed } \\
(\$ 49)\end{array}$ \\
\hline $\begin{array}{l}\text { Flash for Camera } \\
(\$ 20)\end{array}$ & $\begin{array}{l}\text { Hands free auto kit } \\
(\$ 50)\end{array}$ & $\begin{array}{l}\text { Battery: Upgrade } 8 \mathrm{hr} \text { to } 24 \mathrm{hr} \\
\text { (\$99) }\end{array}$ \\
\hline $\begin{array}{l}\text { Camera: } 5 \text { Mega Pixel } 3 \text { x zoom } \\
(\$ 99)\end{array}$ & $\begin{array}{l}\text { E-Wallet } \\
(\$ 25)\end{array}$ & $\begin{array}{l}\text { Leather case } \\
(\$ 29)\end{array}$ \\
\hline
\end{tabular}




\begin{tabular}{|c|c|}
\hline \multicolumn{2}{|l|}{ Page 4/4 } \\
\hline Feature (Price) & $\begin{array}{l}\text { Would you buy this feature } \\
\text { for the price showm } \\
\text { in parentheses after features's }\end{array}$ \\
\hline \multicolumn{2}{|c|}{ Click on only ONE of the following 6 phone concepts } \\
\hline Nakia 6800 (\$199) & $r$ \\
\hline Dacklberry 7100 ( $(\$ 299)$ & 6 \\
\hline Samsuna $700(\$ 349)$ & $r$ \\
\hline Palmone Treo 650 (\$399) & $c$ \\
\hline Plackberry 7510 (\$499) & r \\
\hline SonvEriosscon Pgoo (4699) & $r$ \\
\hline \multicolumn{2}{|c|}{ Now you can select each feature separately } \\
\hline Mnikevooard lnout (\$0) & CYes $\mathrm{C}_{\text {No }}$ \\
\hline 12. Key number nad $(50)$ & $r Y_{e s} \sigma_{\mathrm{No}}$ \\
\hline Stvlus i Touchsoreen innut (\$30) & $r_{\text {Yes }} \mathrm{r}_{\text {No }}$ \\
\hline Euetooth (\$49) & $C$ Yes $\mathrm{ONO}_{\mathrm{NO}}$ \\
\hline USP connection (\$15) & $C_{Y e s} \mathrm{ONO}_{\mathrm{NO}}$ \\
\hline WiFi wiredess networking (f49) & $r_{\text {Yes }} \Gamma_{\text {No }}$ \\
\hline Intrared (\$5) & $r_{\text {Ves }} r_{\mathrm{NO}}$ \\
\hline Processor: $166 \mathrm{MHz} 3 \times$ faster (\$49) & $\sigma_{\text {Yes }} \mathrm{C}_{\text {No }}$ \\
\hline Eurosesn conpatiolilis $\times(\$ 30)$ & $r_{\text {Yes }} r_{\text {NO }}$ \\
\hline
\end{tabular}

S. Virtual Stock Market... $-\mid[|x|$ Ele Ecit View Favorites " :

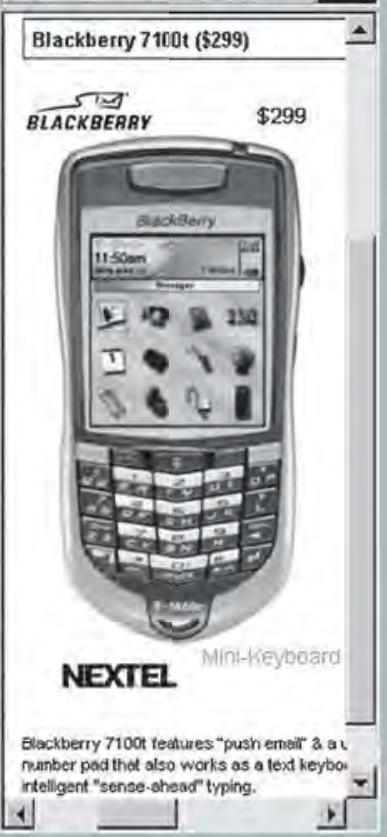

FIGURE 2:

Updated Multi-Screen User Interface for Survey and Trading

a) Survey of self preferences showing a mutually exclusive phone choice at top, and nine binary choices below
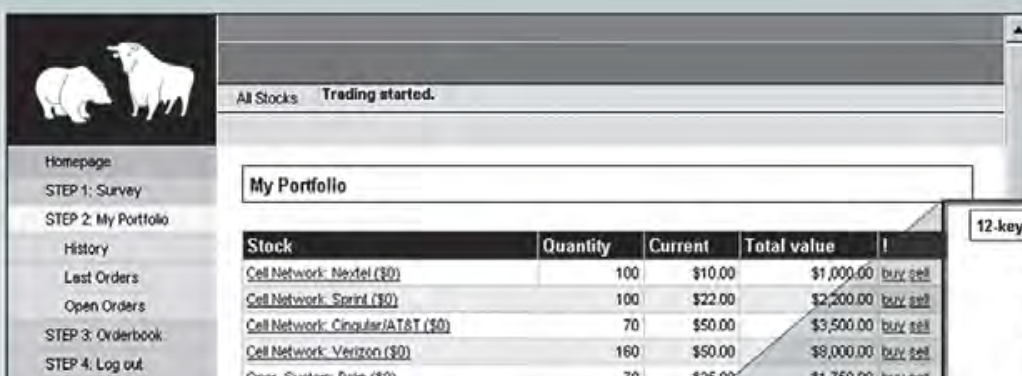

\section{My Portfollio}

\section{Stack}

Cell Nitmork Natel (c9)

Cellntwoek Sairl (99)

Cellnetwork ChatsariATSTI50)

Cell patumerk Verizon (Y)

Qeet Sytert Punctor

onet System Macrosot [940)

Pustre Mal mode [310]

E.woed (925)

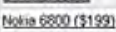

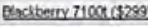

Sunsing i700 (5349)

Pancone Treo 85015389

Eexchenry 7510 (4a92)

Senvericuson 8900 (8589)

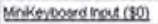

12 ter number ond isos

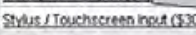

Euetooth (349)

US8 conoection [15:

Wfi watenst netwockinai349]
Quantity
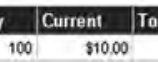

100
70
160

100
70
160
70

$70 \quad \$ 2500$

$130 \quad 55599$

$128 \quad 31900$

$100 \quad \$ 3500$

$70 \quad 350.00$

\begin{tabular}{|r|r|}
160 & $\$ 1400$ \\
330 & $\$ 2000$
\end{tabular}

350
$100 \quad \$ 2000$
53300

100
50 $\$ 23300$

$130 \quad \$ 1400$

$100 \quad 82500$

$100 \quad 52200$

\begin{tabular}{ll}
100 & 52200 \\
\hline 100 & 52750 \\
\hline
\end{tabular}

\begin{tabular}{|l|l|}
100 & $\$ 27.50$ \\
\hline 100 & 32500 \\
\hline 180 & 53000 \\
\hline
\end{tabular}

Portioso vela

cosh

Total value

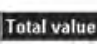

$\$ 1,00000$ bans

ans 8 :

$\$ 2,200.00$ ber tat?

$\$ 3,50000$ buy tet

$\$ 9,00000$ ber 쳐 혀

$31,750.00$ bersed

$\$ 7,79670$ ans

$32,451,00$ bar seil

33,80000 ens set

$83,500.00$ bur 1 제

$32,240.00$ bay is

\$6,50000 burs 0 as

$\$ 5,300.00$ ber ial

$\$ 1,000,00$ exp 281

$\$ 1,82000$ ber tot

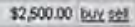

52,20000 banzel

$\$ 2,750,00$ bur 2011

32,60000 bers sel

$35,400.00$ ver sel

$32,500.00$ bery txt

$\$ 66,800.70$

$\$ 2,428.20$

$\$ 69,237.90$

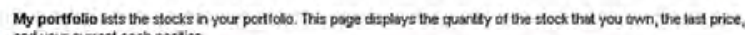

and your current cash postion.
Vou may also clck on "history" to view a ist of your past transactions. "Open orders" alows you to edit of cancel your

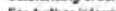

12.key number pad (50)

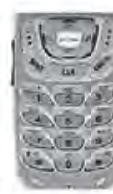

tradbons. 12 bemon sumber pad tor easy telephone dith

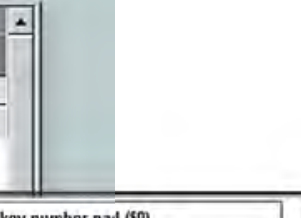

Stock Information

The
phone
ledures
o

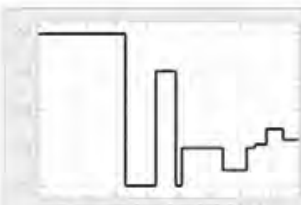

Last price
Last Voleme

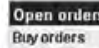

Buy orders Sell orders

\begin{tabular}{lllllllllll}
\hline $\begin{array}{llllll}1000 \\
1000\end{array}$ & 1000 & 10.00 & 2000 & 2200 & 2400 & 2500 & 40.00 & 4900 & 4900 \\
25 & 50 & 55 & 100 & 11 & 56 & 5 & 10 & 100 & 100 \\
\hline
\end{tabular}

10
interface showing the stock portfolio, and details such as name, image, pricing history, and the order book 
TABLE 2:

Comparison of Preference Markets with Conventional Methods

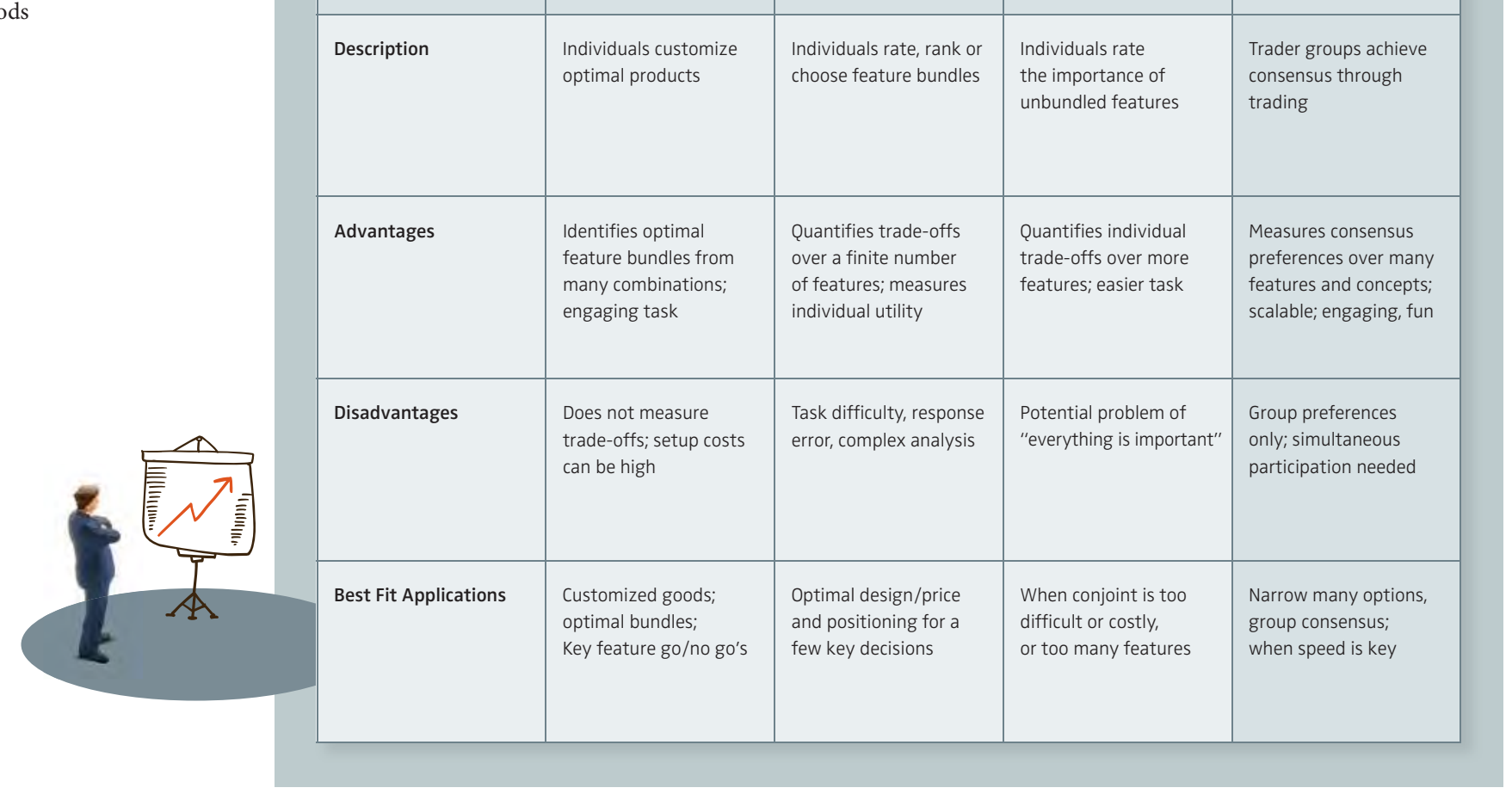

\section{Testing Preference Markets with MBA Students and Corporate Employees}

Two studies were designed to check whether the anticipated advantages can be realized in real product development settings. The smartphone product category was chosen to test scalable preference markets, first with MBA students (116) at a major Western U.S. Business School in a laboratory-like setting, then with managers and engineers (63) at a multinational corporation in a field test. The test involved 56 different design and concept stocks (see Figure 1 on the page before for pictures of features and their levels).

The objective of the study was to test the tools used for the survey as well as some key aspects of preference markets: scalability, flexibility and learning. In advance of trading, each participant completed (1) a self survey, as shown in Figure 2(a), to be compared with (2) a second survey of expectations of others. The stock trading user interface, depicted in Figure 2(b), provided traders with short descriptions and images and real-time trading information (see Figure $2 \mathrm{a} / \mathrm{b}$ on page before).
The real experiment was conducted at a large U.S. firm's corporate headquarters, with over $60 \%$ of participants accessing the market remotely from their offices. The remote participants learned how the experiment worked through a live, 15-minute video webcast with audio questions and answers. This experiment employed the same user interface and experimental design as the first study.

During the 50 to 60 minute duration of the experiments, traders attempted to maximize the value of their respective portfolios, including the market value of all stocks and cash. Participants can either buy or sell shares of stocks based on the comparison of the current market price of a stock and their assessment of the stock's true value. For example, if a participant thinks that the predicted market share for a feature (e.g., "operation system Palm") is too low (i.e., the current price for this stock at the market is too low), the participant can buy shares of this stock. The market pricing mechanism incorporates this participant's information, because buying shares increases the price of this stock. 


\section{Evaluation of Preference Market Data Compared to Survey Data and Other Forms of Market Research}

$>$ Trading stocks helps to converge towards a consensus In both studies, respondents are accurate in estimating each other's preferences. Whereas surveyed expectations of others are biased by participants' own preferences, these biases are overcome in the stock trading data by the market pricing mechanism. Further, trading stocks results in a significant amount of learning among traders. Specifically, traders update their beliefs about others based on the stock prices they observe. So, it appears that the process of trading causes participants to converge towards a consensus of opinion. The learning aspects of scalable preference markets could be particularly useful for product categories in which individual new product preferences are shaped by others, such as fashion goods, or those with network externalities.

> Trading stocks helps to reduce options to a manageable set Table 2 compares preference markets with other methods, and highlights their scalability. Preference markets complement other methods by narrowing a large number of potential product features and concepts to a manageable set that can be further analyzed at individual level using other approaches. Further, distinct benefits of preference markets over survey-type methods are interaction, competition, and learning among participants. More importantly, preference markets scale up in the number of respondents much more easily than surveys.

\section{$>$ Individual preference cannot be measured}

However, an important limitation of scalable preference markets is that they do not measure individual preferences. Our results demonstrate that markets achieve a consensus about expectations of average preferences, and do not provide insight about distinct individuals. To measure heterogeneity, methods such as conjoint analysis are better suited to the task (see Table 2 on page before).

$>$ Trading software and infrastructure are required Implementation of preference markets in firms requires the firm, or outside consultants it may engage, to develop trading software and infrastructure. Respondents need to be taught the mechanics of trading and the underlying meaning of each stock. The key outcomes, the stock prices themselves, become known to all traders immediately, so data security

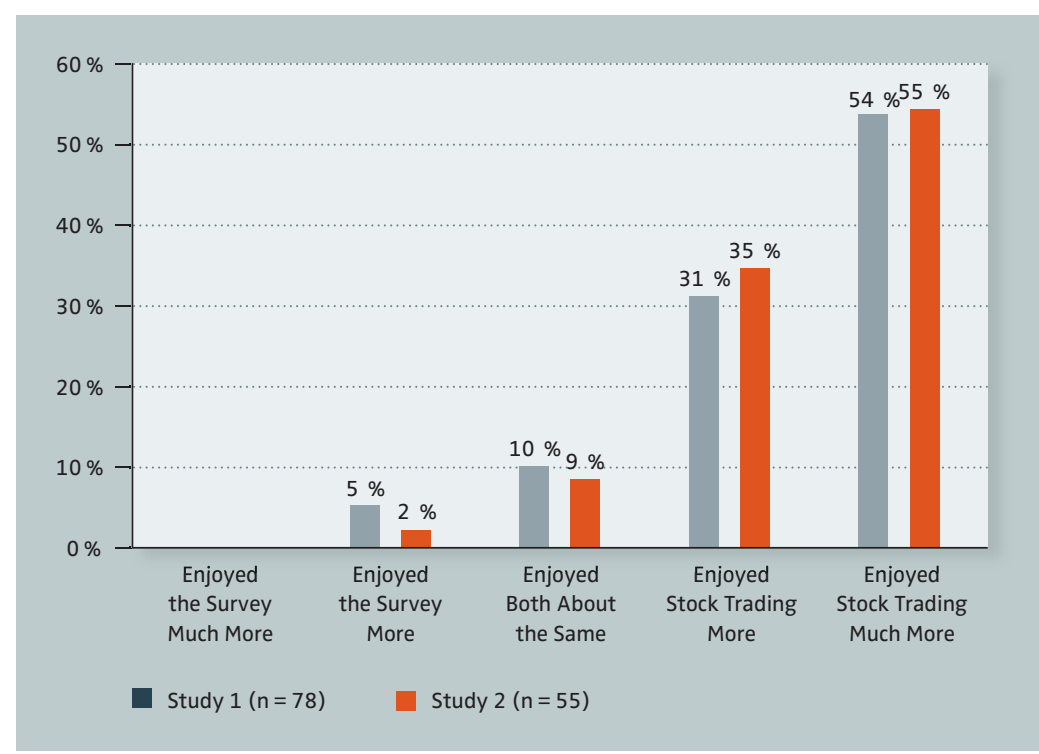

may pose a problem. And the market mechanism itself pulls no punches; the consensus view, whether positive or negative, becomes instantly transparent. Champions of specific product ideas may not readily accept negative outcomes, a challenge with any market research, but one which might be exacerbated by the immediacy of preference markets.

$>$ The method works and is enjoyable for participants Scalable preference markets perform well with students and in the field, with managers and employees trading in an efficient manner. The majority of traders mastered the user interface and were able to trade remotely from their offices. In a post survey, respondents indicated their relative preference between surveys and stock trading. The results are shown in Figure 3.

\section{\) Respondents express a strong prefe-} rence for trading stocks over answering surveys. And they learn from each other while trading, updating their expectations in a way that converges towards a clearer consensus. «
FIGURE 3:

Which Method Did Respondents Prefer: Survey or Stock Trading? 
TABLE 3:

"Triage" of Smartphone New Product Preferences as of 2005

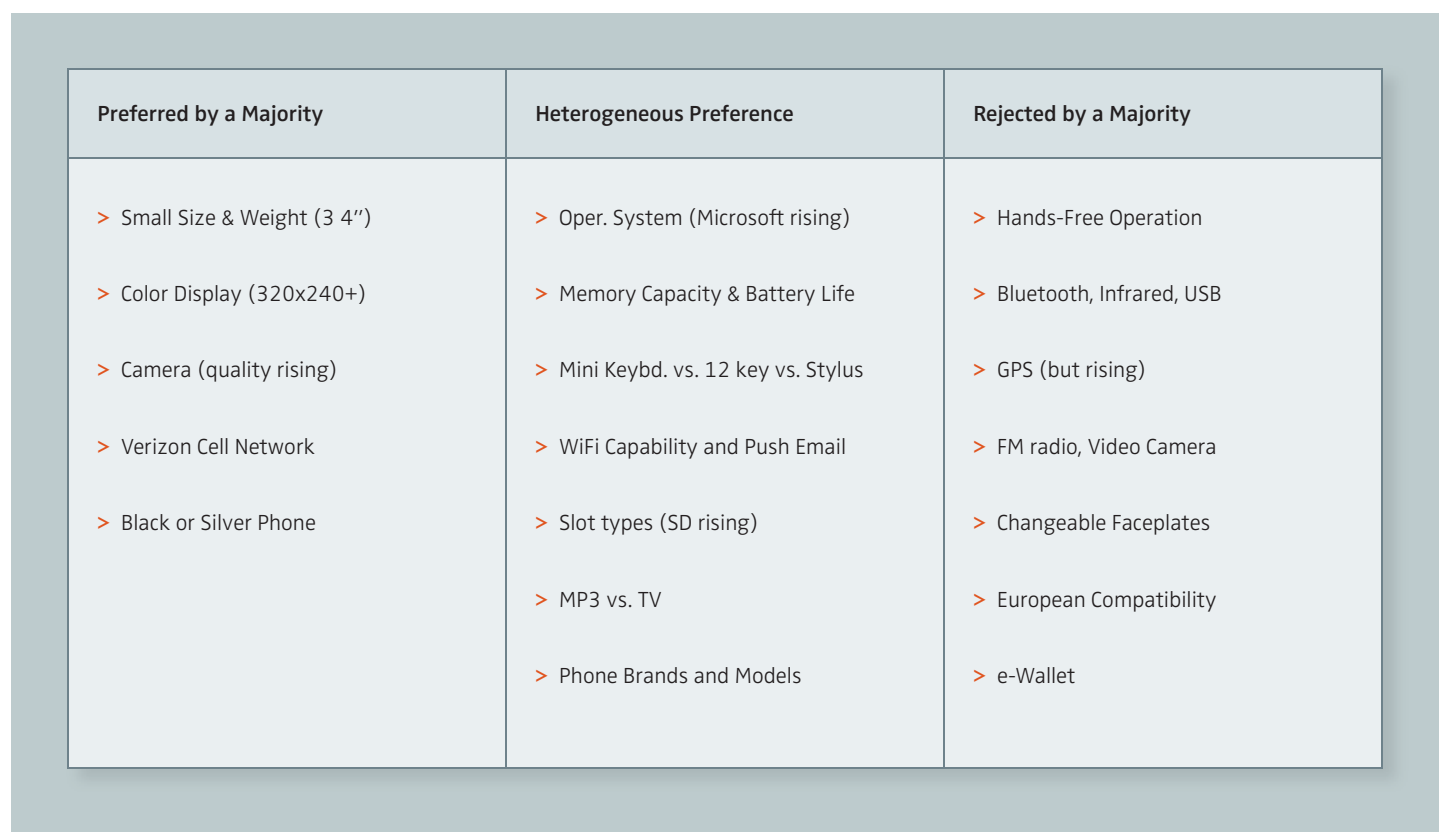

There was near-unanimity in preference for stock trading over surveys. Scalable preference markets differ from surveys in that they include elements of competition, interaction, gaming, learning, and the opportunity to gain recognition and win prizes, which might explain the strong result. In addition, $75 \%$ of the industry experts in Study 2 expressed a willingness to participate in a preference market again.

\section{Evaluation of Preference Market Data Compared to Real Data}

Validating methods with actual, external data poses a challenge in new product development research, as many of the ideas tested may not exist. And even in the case of existing features and concepts, access to accurate data may be limited. Instead, new product releases and comparisons to prior market research studies offer at least some degree of validation of the accuracy of the results. Therefore, results from the survey were compared to real product developments of mobile phones at the time of the experiments.

Looking across both experiments, several clear trends emerge in the data. Five smartphone traits were preferred by the majority, even at a price premium, in virtu- ally every survey and preference market (see Table 3). These five features can be interpreted as "must haves", while ten others were consistently rejected by over two thirds of respondents. The rejected smartphone aspects may represent low-priority, or niche, design considerations. From a marketing perspective, the features in the middle represent differentiation opportunities that merit further study. Scalable preference markets facilitate the "triage" of customer preferences; design teams may prioritize opportunities and focus their product development efforts.

Interestingly, Nokia, Motorola, and BlackBerry launched smartphones in 2006 that largely fit Table 3 and appeared to be converging towards a dominant design. On January 27, 2007, Apple shook up the smartphone market by humanizing the dilemma of keypad vs. minikeyboard vs. stylus user interface with its innovative touch screen interface, which has the added benefit of greater screen real estate in many applications. The iPhone included all of the "preferred by a majority" features identified by our studies, except for the cell network for which Apple opted to strategically partner with AT\&T, and, with the exception of Bluetooth, left out all of the features "rejected by the majority." Thus, the data offers 


\section{FURTHER READING}

a reasonable degree of external validity, leading to the conclusion that preference markets can be quite useful to new product development teams in measuring product concept and attribute preferences as part of NPD.

\section{Conclusion: Can Scalable Preference Markets be Recom- mended in Practice?}

Scalable preference markets offer an effective tool for product development teams, especially when large numbers of design decisions need to be prioritized. For example, the top 5 - 10 stocks may merit further study via conjoint analysis. The number of features and concepts that can be tested scales in the number of traders, with one trader per stock representing a minimum. Respondents express a strong preference for trading stocks over answering surveys. And they learn from each other while trading, updating their expectations in a way that converges towards a clearer consensus.

However, the evidence presented is based on a single product category. It remains to be seen how well the method will translate in contexts in which the innovation type, product type, or customer characteristics vary. Considering the scalability, flexibility, speed, and attractiveness to respondents of preference markets, the authors anticipate that the methodology will gain adherents over time, enabling firms and their product development teams to prioritize the features and concepts that address the consensus opinions of the market. Preference markets may perform in a surprisingly robust way, much as heterogeneous investors do in financial markets, in evaluating numerous industries and firms.
Dahan, Ely and John R. Hauser (2002), The Virtual Customer, Journal of Product Innovation Management $19(5): 332-53$.

Surowiecki, James (2004), The Wisdom of Crowds, New York: Doubleday.

Spann, Martin and Bernd Skiera (2003), Internet-Based Virtual Stock Markets for Business Forecasting,

Management Science 49 (10): 1310 - 26.

\section{KEYWORDS:}

Product Testing, New Product Development, Virtual Stock Markets, Product Design, Preference Markets, Information Markets,

Scalable Market Research 